\title{
HVORDAN EN LOKALTRADITION BLIVER TIL I LYSET AF KULTURMØDETS TREDJE-IDENTITETER
}

\author{
Marianne C. Qvortrup Fibiger
}

\section{Indledning}

“Det er bare overtro, men vores tradition siger ...” Denne sætning har jeg hørt mange gange under mine interviews af srilankansk-tamilske hinduer her i landet, og næsten altid som indledning til en opklarende forklaring på de spørgsmål, jeg har stillet i forbindelse med deres religionsforståelse og deres ritualpraksis, sådan som den kommer til udtryk under de forandrede forhold her i landet. Sætningen rammer lige ned i dette temanummers emner om religion under forandring og kulturmødets tredje-identiteter, idet den tydeligt markerer, hvordan de srilankansk-tamilske hinduer her i landet er fanget imellem to kulturparadigmer: det danske moderne sekulariserede, der kategoriserer de hinduistiske kultiske handlinger som overtro; og det traditionsbaserede, som mine informanter ikke synes at kunne fraskrive sig som troende tamilske hinduer, selvom de godt kan se, at det for en udenforstående kan virke malplaceret og utidssvarende i et moderne vestligt samfund. Det paradoks, de er indfanget i, viser, hvordan de tilskriver traditionen en form for transhistorisk status, selvom det i praksis viser sig, at deres brug af den og tilgang til den har forandret sig.

For traditionen er, ligesom fx kultur, identitet og religion, en dynamisk størrelse og underlagt de historiske- og samfundsbetingede forandringsprocesser, der vedvarende stiller nye krav til den. Og som den relationelle opfattelse understreger, så er hverken tradition, kultur, religion eller identitet noget i sig selv, men kun noget i forhold til noget andet; også selvom de, der føler tilknytning dertil, ofte indtager en essentialistisk position, hvorved fænomenerne bliver forstået som bestandige og upåvirkelige. Som Salman Rushdie udtrykker det: traditionen har ikke rødder, men 'fødder'. Den bevæger sig med andre ord; både når det gælder traditionen, sådan som den kommer til udtryk på et givent sted og på et givent tidspunkt i historien, og så sandelig også tydningen eller tolkningen af den. Dette kommer tydeligt til udtryk i et kulturmøde og ikke mindst i en overflytning af en tradition til helt nye omgivelser. For her mødes traditionen med nogle andre verdenstydninger end dem, den selv har været med til at forme og blive påvirket af. Derved forskydes forholdet til traditionen i to tilsyneladende modsatte retninger. På den ene side opstår der et behov for en revitalisering af det, man vil påberåbe sig som traditionens kerneområder, på den anden side revurderes de, så de stadig kan bruges som udgangspunkt i en verdenstydning under de nye forhold og de deraf følgende nye fordringer til dem. Derved opstår noget tredje, og i tilfældet med de srilankansk-tamilske hinduer i Danmark, en specifik dansk-tamilsk hinduistisk lokaltradition. I denne tematiks sammenhæng er det en pointe - som man måske lidt ironisk kan kalde det tredjes succeskriterium - at de srilankansk-tamilske hinduer, hvis de vend- 
te tilbage til Sri Lanka, ville opleve endnu et kulturmøde med tilpasningsprocesser til følge. For også Sri Lanka er underlagt moderniserings- og transformationsprocesser, der bevæger forholdene bort fra det fastfrosne og til tider idealiserede billede, som de srilankansk-tamilske hinduer her i landet bærer rundt på, og som er det billede, de bruger som sammenligningsgrundlag, når forholdene i Danmark diskuteres.

Det er baggrunden for denne irreversible proces, som den srilankansk-tamilske hindutradition i Danmark er underlagt, jeg vil forfølge i denne artikel. I første omgang ved en teoretisk indkredsning af de centrale begreber kultur og identitet, og $i$ anden omgang ved at sætte begreberne i spil med mit empiriske forskningsområde.

\section{Kultur, identitet og religion}

Selvom begreberne kultur, og identitet er meget omdiskuterede definitorisk, er de alligevel meget brugte, ikke blot inden for kulturforskningen, men også i den offentlige debat. Således er begreberne analogt med ordet myte gledet ind i den generelle sprogbrug, og de har efterhånden antaget kliché-karakter. Men netop fordi alle forholder sig til kultur og identitet i den offentlige sfære, ligesom religion og kultur ofte ligestilles i den politiske indvandrer- og flygtningedebat herhjemme, er det om muligt blevet endnu vigtigere at forsøge at indkredse begreberne. Og fra min synsvinkel er det ikke mindre væsentligt, at de srilankansk-tamilske hinduer qua kulturmødet og gennem indoptagelsen af dansk sprogbrug synes at tage udgangspunkt i disse kategorier eller tilsvarende kategorier i deres selvrefleksion. Men i modsætning til mange etniske danskere, så har religionen en mere åbenlys plads i denne selvrefleksion, også selvom forholdet til religionen har forskudt sig. Religionen er blevet en entitet i sig selv og er ikke blot en del af deres 'way of life' - sådan som de så deres forhold til hinduisme, før de kom til Danmark. Det betyder, at der i Danmark sættes ord på religionens indhold. Og netop derfor reflekteres der anderledes over den som betydningsproducerende fænomen, ligesom man i relation til de omgivende forhold både bevidst og ubevidst udvælger de dele af religionen, som passer til gruppens eller individets behov. I forhold til kulturen har religionens institutionaliserede praksisside, sådan som den kommer til udtryk i templet, fået øget sin betydning og er således blevet en central kulturmarkør i Danmark. I forhold til identitet tilvejebringer religionen normer og et syn på verden og dens indretning, som den identitetssøgende kan forholde sig til og enten indoptage eller tage afstand fra i sit forsøg på at forholde sig til sig selv som individ i relation til omverdenen.

I dag er man stort set enige om at fraskrive kultur og identitet nogen form for lukket henvisningskarakter. I forbindelse med kulturbegrebet taler man fx om det multikulturelle menneske, om kulturel kreolisering, ${ }^{1}$ om kulturelle hybridformer og om kulturelle

\footnotetext{
${ }^{1}$ Udtrykket kreolisering stammer fra lingvistikken, hvor det udtrykker mødet mellem to eller flere sprog,
} 
pendlerstrategier, hvor man pendler imellem forskellige kulturer afhængig af situation og ydre kontekst. ${ }^{2}$ Man er med andre ord nået til den erkendelse, at kultur eller den kulturelle konstruktion af virkeligheden udgør et patchwork, konstrueret ud fra de mange diskursuniverser eller livsverdener, som mennesket bevæger sig mellem og påvirkes af. Og vil jeg tilføje, som mennesket gør og har gjort det i enhver kontekst. Lige meget hvilken kultur man retter sit blik imod, består den af forskellige diskursuniverser, inden for hvilke mennesket må bevæge sig og tilpasse sin adfærd i forhold til de rammer, et givet forhold udstikker. Der vil fx i enhver kultur være forskel på, om man bevæger sig i privatsfæren eller i den offentlige sfære, om man er far med en øverste bemyndigelse, eller om man er en del af et arbejdsfællesskab med en bestemt kodificeret hierarkisk opdeling. Samtidig er der også forskel på, om man ser på kultur ud fra en kollektiv strategi som en samfundskonstituerende faktor eller som en personlig betydningsbærer, sådan som fx Bradd Shore (1996) gør opmærksom på ved at understrege, at kultur både er en dimension i det menneskelige sind og en del af den sociale virkelighed.

En opdeling som den skitserede indebærer, at man som kulturforsker må tage hensyn til begge dimensioner og hele tiden sondre imellem disse to betydningsdimensioner, som kulturen bevæger sig på. Den ene dimension kommer til udtryk i adfærds- og handlingsmønstre, som en given tradition danner udgangspunkt for - og her tænker jeg ikke blot på en 'medløberadfærd', der følger traditionen, den kan lige så godt komme til udtryk som en modreaktion mod de adfærdsmønstre, som traditionen menes at plædere for. Den anden dimension er enkeltmenneskets tolkning og brug af den første dimension, hvilket bl.a. kan komme til udtryk i en specifik selvforståelse.

En af de vigtigste faktorer i en kulturforståelse er således at begribe kulturens indre dynamik og fortsatte bevægelighed i flere dimensioner, men på to overordnede og indbyrdes afhængige niveauer, det kollektive og det individuelle, gennem hvilke kulturens symbolsystem både går i dialog med det omkringliggende samfund og med dem, der formidler kulturen. Det kollektive niveau henviser til den situation, hvor mere end en person vedkender sig nogle fælles eksistentialer: det være sig en fælles historie, en fælles skæbne, fælles traditioner, der for dem danner udgangspunktet eller rammen for et fællesskab. Så er der det individuelle niveau, hvor den enkelte via en accept af at høre til en fælles kultur, fortolker kulturen ud fra personlige behov og interesser, hvilket både

hvorefter en sprogligt turbulent tid følger, før der igen skabes sproglig stabilitet. Men det bruges også inden for musik og i litteratur- og filmvidenskaben, hvor begrebet udtrykker en mere eller mindre bevidst udvikling af en blandingsform imellem stilarter. I forbindelse med kulturforskningen dækker det over en sammenkobling af flere forskellige kultursæt, så der skabes en form for hybrid. Se fx Mørck 1998, 14 og 77. Kritikken af såvel begrebet kreolisering som hybridkultur går ud på, at begreberne synes at forudsætte en blanding af to eller flere kulturer, som i udgangspunktet synes hele eller upåvirkede.

${ }^{2}$ Udtryk som Mørck (1998) diskuterer brugen af. 
kan foregå ubevidst og bevidst. Ubevidst, hvilket er det mest almindelige, hvor man qua opdragelsen tager udgangspunkt i de her igennem udstukne rammer i en fortolkning af sin livssituation og af verden, og bevidst, hvor man manipulerer med dem eller bruger dem med den hensigt at ville sikre egne interesser. Tilgangen til kultur vil derfor være under bestandig bevægelse og afhænge af de eksterne og interne fordringer til den. Således er det en pointe, at kultur altid vil reflektere specielle interesser, holdninger og behov, som samtidig har hentet sin legitimitet i kulturen selv. En dialektik der også er til stede i en identitetsdannelse.

Det, der adskiller en person, som bevæger sig inden for én kulturs område fra en person, der bringer en kultur med sig til andre omgivelser med andre livsverdener, er diskursspringet mellem de forskellige kulturlag. Fx konfronteres man med helt anderledes idealer, individ- og verdenssyn. Negativt kan det skabe kommunikative misforståelser eller en grundlæggende mangel på forståelse. Positivt kan man i mødet med et nyt samfund og en ny kultur få endnu en inspirationskilde til fortolkning af verden. Man kan med andre ord se kulturmødet som muligheden for at frigøre sig fra kulturbetingede fastlagte roller og mønstre, eller man kan finde et hidtil uset potentiale i sin medbragte kultur til at tolke rollerne og mønstrene anderledes, hvorved dens status som betydningsbærer opretholdes. Yvonne Mørck gør i denne forbindelse opmærksom på, at der er danske forskere som Flemming Røgild og Mehmet Ümit Necef, der henviser til storbyen som det sted, hvor man kan frigøre sig fra tidligere bånd, og hvor en større vifte af sociale og etniske identiteter kan realiseres (1998, 36). Dette kan jeg underbygge under henvisning til flere af de interviews, jeg har haft med srilankansk-tamilske hinduer i Danmark. Fx var der en kvinde på 26 år (der kom til landet i 1993 via et arrangeret ægteskab), som fortalte mig følgende: "I Sri Lanka var jeg bange for mine forældre. Jeg skulle altid spørge mine forældre, før jeg gjorde noget. Her i Danmark er jeg helt fri. Her spilder jeg fx tiden med at tale med mine venner. Det fik jeg ikke lov til i Sri Lanka."

Konkluderende kan man sige, at kultur, som den her er beskrevet, er en dynamisk størrelse med flere ubekendte og derfor umulig at indfange som en konstant i et empirisk arbejde med en given gruppe mennesker. Alligevel er det en størrelse, som man bliver nødt til at forholde sig til, da begrebet dækker over det, som i gruppens eller i enkeltindividets bevidsthed er til stede som en konstant, og som er med til at markere en form for tilsyneladende demarkationslinie imellem mig/os og de andre. Det samme gælder begrebet identitet, der, selvom det er en relationistisk konstruktion, alligevel danner udgangspunkt for en egenforståelse. Identitet er en markering af et personligt rum i verden, hvorved man hører til i verden, som en eksistens andre bør forholde sig til. Ordet identitet betyder egentlig 'at være det samme som sig selv', hvilket er det modsatte af forskel. Ordet handler derfor både om ligheder og forskelle. Social identitet er synonym med gruppetilhørsforhold, og kulturel identitet betyder ikke, at de, som deler identiteten, har samme kultur, men at de ud fra en subjektiv synsvinkel oplever det sådan. Dvs. selvom der hentes komponenter fra kulturen til en identitetsdannelse, så 
rækker kulturen ud over denne. Den er også eksistentielt betinget, hvorfor de givne forhold og individets tolkning af kulturen griber ind.

Dette samspil mellem det tilsyneladende kollektive og det individuelle berører det, som Paul Connerton (1989) kalder et samfunds kollektive hukommelse, hvilket berører spørgsmålet om, hvordan et samfund kan være traditionsbevarende. På den ene side anfægter han, at man kun kan tale om en individuel hukommelse (1989, 1), men han anerkender på den anden side, at den kollektive hukommelse beror på samspillet mellem tre former for hukommelse, der alle er at finde hos det enkelte individ, og som i større eller mindre grad kan være delt af andre: den personlige hukommelse, der refererer til den individuelles erindring af hans eller hendes fortid; den kognitive hukommelse, der bevæger sig på det semantiske niveau, og hvor man i modsætning til den personlige hukommelse ikke behøver at forholde sig til den kontekst eller episode, hvor den kognitive hukommelse er blevet implementeret. Og til sidst den reproducerende hukommelse, hvor man har evnen til at reproducere en given handlingsakt, som man en gang er blevet præsenteret for, eller som man har tillært sig (1989, 21-23). Det er denne kombination af individuelle hukommelsesdomæner, der spiller ind i en bestemmelse af fx kultur, men det er især den reproducerende hukommelse, som er med til at stadfæste, hvad der kan betegnes som en tilsyneladende fælles hukommelse, sådan som den kommer til udtryk i det, man er enige om at betegne som tradition. Den reproducerende hukommelse kan $\mathrm{fx}$ ligge til grund for den religiøse kult og kan gå ind under den kategori, som Connerton betegner som ihukommende ceremonier (commemorative ceremonies), der bygger på kropslige automatismer eller vanehandlinger (1989, 5). Her er det centralt, at Connerton understreger, at netop ritualet i modsætning til myte har et mindre variationspotentiale indbygget $(1989,57)$. Jeg vil i det følgende diskutere, hvilken betydningstilskrivning religion har i et moderne samfund, og jeg vil forsøge at vise, hvordan det netop er blevet det institutionaliserede ritual, som er blevet omdrejningspunkt for de troende srilankansk-tamilske hinduers opfattelse af deres fælles traditionelle referenceramme her i landet.

\section{En lokaltradition opstår}

Det var i 1983, da borgerkrigen i Sri Lanka for alvor brød ud, at tamilske flygtninge begyndte at komme fra Sri Lanka til Danmark. De blev kategoriseret som såkaldte de facto-flygtninge og fik midlertidig opholdstilladelse. Det var overvejende unge mænd, som flygtede, fordi de enten direkte eller indirekte havde været involveret i frihedskampen via tilknytning til en af de tamilske militante oprørsgrupper, primært LTTE, også kaldet de tamilske tigre, eller ved at have familiemedlemmer tilknyttet, eller blot ved offentligt at have ud talt sig positivt om bevægelsens virke.

Nu 18 år efter tegner billedet sig anderledes. Mange af mændene har stiftet familie eller er blevet sammenført med den familie, som de måtte forlade i Sri Lanka. Og familierne har efterhånden slået rødder. I dag tæller de 8-8.500. De fleste voksne har gået eller går i sprogskole, mange har fået arbejde, og børnene går i den danske folkeskole, hvor de klarer sig godt, og de taler efterhånden hellere dansk end tamilsk indbyrdes. 
De fleste tamiler vil gerne tilbage til Sri Lanka, hvis de politiske forhold tillader det, men de tror ikke på nogen snarlig løsning på konflikten. De er begyndt at indstille sig på at blive i Danmark, hvilket officielt viser sig ved at over 5000 af dem har opnået dansk statsborgerskab, og kulturelt ved, at de srilankansk-tamilske hinduer har mobiliseret penge til at købe en nedlagt lagerbygning i Herning, som de fik ombygget og indviet til tempel i september $1996 .{ }^{3}$ Over 1000 srilankansk-tamilske hinduer var til stede ved denne begivenhed. Man kan nu tydeligt skimte konturerne af en fælles srilankansktamilsk hinduistisk gruppeidentitet, som templet eller den religiøse institution står som garant for.

En institutionalisering af religionen synes at kunne passe til det moderne samfund, der bl.a. er kendetegnet ved, at religion indtager en plads ved siden af andre ekspertsystemer, der fungerer inden for hvert deres regi og med hver deres vidensfelter, sådan som bl.a. Anthony Giddens karakteriserer det. Også Niklas Luhmann har gjort sig lignende overvejelser og understreger, at det moderne samfund er kendetegnet ved, at det bygger på en funktionel differentiering, hvor hvert delsystem har sin specifikke funktion, uden at de samlet lader sig centralt styre af en eller anden form for overordnet autoritet. Derved findes der heller intet fælles udgangspunkt for meningstilskrivning, og Luhmann kalder derfor det moderne samfund for polycentrisk. Samfundets enhed ligger i stedet i dets funktionssystemers forskellighed, hvor hvert enkelt system kun er ansvarlig for sin egen funktion.

Samfundet mister i denne forbindelse sin stabilitet, og tolkningsprocesserne mangler entydighed. De flygtninge eller indvandrere, der kommer til et sådan samfund, vil ikke kunne finde et stabilt verdensbillede, et fælles udgangspunkt eller en agent, som alt andet peger hen imod, og som de kan lære at kende og blive fortrolige med i forsøget på at forstå det samfund, de er blevet en del af. Derudover konfronteres de med en skepticisme og en ironi, der udtrykker, at heller ikke vi, der er en del af dette moderne samfund, synes at ville acceptere dets grundvilkår. Og sidst, men ikke mindst, kan de ikke finde sig en fast defineret plads i samfundet, fordi de funktionelle systemer går på tværs af sandsynlige eller åbenbare sociale klasser og skel. Individet er i lyset af moderniteten blevet omdrejningspunktet, ligesom det er blevet en homo viator, et rejsende menneske, som rejser eller diffunderer fra system til system eller på en gang forholder sig til flere systemer. Det hører ikke blot til ét og kun ét delsystem. Derfor må det være bærer af sig

\footnotetext{
${ }^{3}$ Indtil 1994 havde de intet officielt mødested for deres tilbedelse. I 1994, efter anmodning fra tamilerne, stillede Herning kommune en taglejlighed i en offentlig bygning til rådighed. Også den blev indviet til tempel og dedikeret til Gane_a. Den var dog for lille, og indsamlingen til og søgningen efter noget andet blev påbegyndt. Desuden blev de tamilske hinduer officielt anerkendt som trossamfund i Danmark i 1998, hvilket har virket befordrende på tempelbyggeriet og på antallet af tamilske hinduer, der kommer til $p_{-} j_{\text {. }}$.
} 
selv eller være noget, som eksisterer på sine egne betingelser. ${ }^{4}$ Denne frisættelse ligger i ordet selvreference, hvorfor en identitets- eller identifikationssøgning synes at blive mere påkrævet, idet det er en måde, hvorpå man kan indkredse det psykiske system den mindste enhed i den mængde af funktionssystemer, som man på kryds og tværs vælger at være en del af.

For at religion som subsystem skal kunne kommunikere med det individualiserede psykiske system, kræver det, at religionens tematiseringer må være adækvate i forhold til det psykiske systems forståelse af sig selv. Det betyder, at det religiøse system snarere gøres til genstand for refleksion end for interpretation. Dvs. der reflekteres over religionen som forklaringsmulighed. Luhmann skelner imellem interpretation og refleksion ved at at betragte interpretation som et selvreferentielt systems bestræbelse på at tilpasse sin selektion efter omverdenen og refleksion som en forskelssætten imellem system og omverden - således vil systemet forholde sig til det valg af muligheder, som omverdenen i sin kompleksitet udbyder, og vælge det der passer i en given situation for det givne system. Dvs. der bliver ikke nødvendigvis, som ved interpretation, indoptaget noget i systemet. Refleksionen bliver brugt for at systemet kan forholde sig til sin omverden.

Ud fra denne tematisering af verden kan man ikke således ikke forvente, at religionen har en fast tilhængerskare, hvis ikke den vedvarende bliver revideret i forhold til tilhængerskarens behov. Tilsvarende kan man forvente, at den bliver brugt efter forgodtbefindende i en konkurrence med andre verdenstydninger, evt. kædet sammen med andre religiøse systemer i det psykiske system, der skaber sin helt private kosmologi. Og helt i tråd med andre sociologer som Talcott Parsons, Peter Berger, Thomas Luckmann og Robert Bellah beskriver Luhmann den privatiseringsproces, religionen er blevet underlagt i forbindelse med sekulariseringen, hvorved den har mistet offentlig relevans. ${ }^{5}$ Luhmann går dog videre ved at hævde, at det er en privatiseringsproces, alle systemer er underlagt. Det individuelle psykiske system vælger selv sin religiøse overbevisning, men det gælder også i forbindelse med politik, økonomi o.l.

Luhmann mener ikke, at religion har udspillet sin rolle i det moderne samfund tværtimod. Den er netop med til at indsætte nogle fastsatte eksistentialer, så noget ubestemmeligt bliver til noget bestemmeligt. Religionens primære funktion er således den ordnende funktion, der angår verdens bestemmelighed. Men idet Luhmann samtidig understreger, at det ikke er mennesket, som artikulerer det religiøse og giver det en social skikkelse, men omvendt det sociale, der artikulerer det religiøse gennem kommu-

\footnotetext{
${ }^{4}$ Luhmann holder ikke af ordet subjekt, men erstatter det med "det psykiske system”, for som han siger: Hvordan kan subjektet være subiectum for sig selv og for alt andet? (1997, 92).

${ }^{5}$ Som kort oversigt, se Beyer 1994, 70-96.
} 
nikationsmediet tro, ${ }^{6}$ og bl.a. giver det en menneskelig skikkelse, så er det religiøse uløseligt kædet sammen med det sociale, hvorved religionen må ændre sig i takt med den samfundsmæssige ændring.

I fordringen til religionen, der i sidste ende beror på det psykiske systems refleksive brug af denne, er det også vigtigt, at de srilankansk-tamilske hinduer i mødet med den danske individ-orientering, som bl.a. børnene oplever i skolen, ser det som en legitim tilgang, der ikke skal undertvinges. De er begyndt at tænke i individuelle kategorier, de er ikke blot en del af familien, men de udgør en entitet i sig selv, hvorfor de reflekterer over deres personlige trosforhold. Det betyder, at børnene stiller deres forældre spørgsmål om deres tradition, og hvorfor de i flere henseender adskiller sig fra deres klassekammerater. Spørgsmålene kan fx dreje sig om, hvorfor de ikke må spise kød om fredagen, hvorfor de ikke holder juleaften, hvorfor de skal gå i templet. Børnenes øgede refleksion over tingenes tilstand forstærker også refleksionen hos deres forældre, som skal forsøge at finde svar på de stillede spørgsmål.

\section{Traditionsbevidsthed og traditionstilpasning}

Det er tydeligt, at mødet med det danske samfund både har skabt en nødvendig traditionstilpasning og en øget traditionsbevidsthed hos den srilankansk-tamilske gruppe. Men den øgede refleksion har ikke blot skabt en styrket traditionsbevidsthed, men også en traditionskritik blandt alle generationer af tamiler i landet. Traditionsbevidstheden ytrer sig bl.a. i templet, hvor man på flere områder, fx i forhold til selve udførelsen af $p \_j$ (gudstjeneste) og i overholdelsen af renhedsforskrifter i den forbindelse, er blevet mere ortodokse, end det var tilfældet i Sri Lanka. Men når det gælder andre livssfærer, har man indoptaget store dele af den danske livsform og dispenserer her fra, hvad traditionen fordrer. Her differentierer de srilankanske tamiler tydeligt imellem de forskellige ekspertsystemer, hvorfor de lader de religiøst betingede renhedsforskrifter falde, når det gælder andre artikulationssfærer. Det kommer bl.a. til udtryk på arbejdsmarkedet, hvor de ud fra en religiøs synsvinkel hellere påtager sig urene jobs frem for at være arbejdsløse. Fx møder man tamiler på Danpos fjerkræslagterier. Således lader de i denne kontekst det traditionelle trosforhold falde. Noget tilsvarende gør sig gældende med juleaften, som mange holder i en modificeret udgave for børnenes skyld, så de ikke udelukkes fra det fællesskab, som udspiller sig i skolen. Disse eksempler betyder dog ikke, at traditionen har udspillet sin rolle, men dens virkeområde har indsnævret sig til færre udvalgte områder, hvor der til gengæld værnes om dens position og betydning.

${ }^{6}$ Og her kan man (jævnfør Connerton) nævne ritualet, altså troens agentside, som en vigtig artikulationsfaktor. 
Det er denne kombination af øget traditionsbevidsthed på den ene side og traditionstilpasning på den anden, som fører til en revurdering af traditionsgrundlaget, så traditionen kan kommunikeres både indadtil i gruppen og med det enkelte psykiske system og udadtil med det omkringliggende samfund, der danner udgangspunkt for kulturmødets tredje-identiteter.

\section{Konklusion}

I Sri Lanka er der en sekulariserings- og dermed privatiseringsproces i gang, hvor hinduismen ændrer sig i tråd med samfundets fordringer. Her har behovet for religiøs legitimering i forbindelse med den politiske konflikt også ændret på religions brugen. I Danmark derimod skal hinduismen forholde sig til et samfund, hvis udvikling den ikke har været involveret i. Det kræver, at religionen tilpasses de nye fordringer, som de srilankansk-tamilske hinduer møder i deres egen tilpasningsproces; samtidig skal religionen kunne legitimere, hvorfor de srilankansk-tamilske hinduer skiller sig ud. Den srilankansk-tamilske hinduisme skal således tilpasses, uden at dens særkende forsvinder. Her er det min overbevisning, at templet er et vigtigt omdrejningspunkt, hvor troen kommer til udtryk i handling gennem tilbagevendende og genkendelige ritualer, gennem hvilke de srilankansk-tamilske hinduer bindes sammen i en fælles handlingsakt, der markerer deres fælles selvreferentielle rum. Religionen er tilsvarende blevet tilpasset det moderne samfund ved at udgøre et specifikt funktionssystem på lige fod med andre funktionssystemer.

Det umiddelbare brud imellem tradition og modernitet er således ikke nødvendigvis et skisma ej heller for srilankansk-tamilske hinduer i Danmark. Netop tradition og modernitet synes at kunne gå hånd i hånd. Det nye tolkes, så det passer til det gamle og vice versa. Traditionen tilpasses, så den kan indgå i den moderne verdensanskuelse og dagligdag, hvorfor religionen som konsekvens har institutionaliseret sig i Danmark. Således har templet i Danmark øget sin betydning som både kulturel og religiøs identitetsmarkør for de srilankansk-tamilske hinduer i landet. Det kommer bl.a. til udtryk i den store vægt, der lægges på ortopraksis i forbindelse med selve $p \_j \_e n$, og som er et udtryk for en øget bevidstgørelse hos den menige tempelbruger, som man ikke finder tilsvarende i Sri Lanka.

Pointen med dette eksempel er, at tradition og modernitet skal behandles som kongruente frem for sekvente størrelser. Ikke fordi de smelter sammen, men fordi de gensidigt påvirker hinanden inden for bestemte semantiske eller kommunikative rum, hvor de hver især har et bud på tydning eller betydning. Det er netop samspillet mellem tilsyneladende kontrasterende elementer som fx tradition og modernitet, kontinuitet og forandring, det religiøse og det sekulære rum, der giver hinduismen i Danmark dens specifikke karakter, hvorved en lokaltradition opstår.

\section{Litteratur}

Beyer, Peter

1994 Religion and Globalization, London. 
CONNERTON, PAUL

1989 How Societies Remember, Cambridge.

GIDDENS, ANTHONY

1990 The Consequences of Modernity, Cambridge.

1991 Modernity and Self-Identity. Self and Society in the Late Modern Age, Cambridge.

LUHMANN, NIKLAS

1984 Soziale Systeme. Grundriss einer allgemeinen Theorie, Frankfurt a.M.

1989 “Die Ausdifferenzierung der Religion”, Gesellschaftstruktur und Semantik 3, Frankfurt a.M. 258-357.

1992 Funktion der Religion (3. Auflage), Frankfurt a.M.

1997 Iagttagelse og paradoks. Essays om autopoietiske systemer. Oversat ved H. Chr. Fink, J. Katlev og O. Thyssen, København

Mørck, Yvonne

1998 Bindestregs-danskere. Fortcellinger om køn, generationer og etnicitet, Frederiksberg.

SHORE, BRADD

1996 Culture in Mind. Cognition, Culture and the Problem of Meaning, Oxford.

WAGNER, PETER

1994 A sociology of modernity. Liberty and discipline, London.

\section{Summary}

The aim of this article, as exemplified by the Srilankan-Tamil Hindus, is to show how religion is changing in a cultural encounter and, in that perspective, how a local Danish-Tamil Hinduism is formed - a local tradition that you will not find anywhere else. This case study illustrates how a third identity comes into being, an identity shaped in the dialectic between the reshaped tradition and the elements of the same tradition that the members consider to be the key elements. It also shows how tradition as well as culture, identity and religion are dynamic phenomena which change along with the new environment and needs of the members.

Marianne C. Qvortrup Fibiger Adjunkt, ph.d.

Institut for Religionsvidenskab Aarhus Universitet 